${ }^{1}$ Assit. Prof. Dr., Bartın University, Bartın, Turkey, kcelik@bartin.edu.tr

ORCID: 0000-0002-4530-1048

Submitted: 6/07/2021

Revised: $24 / 08 / 2021$

Accepted: 16/09/2021

Online Published: 25/09/2021

Citation: Celik, K., The effect of e-service quality and after-sales e-service quality on e-satisfaction, bmij (2021) 9 (3): 1137-1155, doi:

https://doi.org/10.15295/bmij.v9i3.1898

\section{The effect of e-service quality and after-sales e-service quality on e-satisfaction}

E-hizmet kalitesi ve satış sonrası e-hizmet kalitesinin e-tatmine etkisi

\author{
Kamil Çelik ${ }^{1}$
}

\begin{abstract}
This study investigates the effects of e-service quality and after-sales e-service dimensions of ecommerce sites on customers' e-satisfaction. E-commerce site hepsiburada.com operating in Turkey, was selected as an example for their e-commerce website. The survey method collected the data, and 417 hepsiburada.com customers reached by random sampling method were included in the study. ES-QUAL and E-RecS-QUAL scales were used to measure the concepts of e-service quality and aftersales e-service quality. The data were analyzed by confirmatory factor analysis and structural equation model. According to the analysis findings, system availability, fulfilment, responsiveness, and compensation had a significant and positive effect on e-satisfaction, and efficiency, privacy, and contact have no significant and positive effect on e-satisfaction. The findings were interpreted, and suggestions were provided.
\end{abstract}

Keywords: E-commerce, E-service quality, After-sales e-service quality, E-satisfaction, E-S-QUAL, ERecS-QUAL

JEL Codes: M21, M30, M31

Öz

Bu çalışmanın temel amacı, e-ticaret sitelerinin e-hizmet kalitesi ve satış sonrası e-hizmet boyutlarının müşterilerin e-tatmine etkilerini araştırmaktır. E-ticaret sitesine örnek teşkil etmesi amaciyla Türkiye'de faaliyet gösteren hepsiburada.com e-ticaret sitesi seçilmiştir. Veriler anket yöntemiyle toplanmış ve rastgele örnekleme yöntemiyle ulaşılan 417 hepsiburada.com müşterisi araştırmaya dahil edilmiştir. E-hizmet kalitesi ve satış sonrası e-hizmet kalitesi kavramlarını ölçmek için E-SQUAL ve E-RecS-QUAL ölçekleri kullanılmıştır. Elde edilen veriler doğrulayıcı faktör analizi ve yapısal eşitlik modeli ile analiz edilmiştir. Analiz sonucunda sistem uygunluğu, yerine getirme, cevap verebilirlik ve telafi etmenin e-tatmin üzerinde anlamlı ve pozitif etkisinin olduğu, verimlilik, gizlilik ve iletişimin e-tatmin üzerinde anlamlı ve pozitif bir etkisinin olmadığ 1 tespit edilmiştir. Elde edilen sonuçlar yorumlanarak, önerilerde bulunulmuştur.

Anahtar Kelimeler: E-ticaret, E-hizmet kalitesi, Satış sonrası e-hizmet kalitesi, E-tatmin, E-S-QUAL, E-RecS-QUAL

JEL Kodları: M21, M30, M31 


\section{Introduction}

Internet is one of the most critical factors affecting the development of electronic commerce. With technology development, businesses have moved their activities from the traditional environment to the internet environment. Thanks to e-commerce, people have the opportunity to reach the products they desire in more favourable conditions (Bilgihan \& Bujisic, 2014). In addition, factors such as the increasing number of smartphones and applications suitable for mobile devices facilitate access to the internet and support the development of e-commerce (Suki, Ramayah and Suki, 2008).

E-commerce companies have the advantages of being open 24/7 with fewer geographic restrictions and having more products. However, in addition to these benefits, customers face disadvantages such as lack of ability to feel, taste, hear or try before purchasing, needing internet to shop, risk of exposure to credit card fraud and delays in product deliveries. (Niranjanamurthy, Kavyashree, Jagannath, Chahar, 2013; Barenji, Wang, Li, Guerra-Zubiaga, 2019).

While the ratio of e-commerce volume to general trade in Turkey was 9.8 per cent in 2019, it increased by 5.9 points to an average of 15.7 per cent in 2020 . E-commerce in the world grew by 18 per cent on an annual basis and reached 4.3 trillion dollars in 2020. E-commerce volume in Turkey increased by 66 per cent compared to 2019 and increased from 136 billion Turkish Lira to 226 billion and 200 million Turkish Lira.

E-commerce is also among the most dynamic sectors in Turkey and continues to proliferate. Turkey is a country with enormous potential, with 83 million, the majority of whom is young, and 62 million Internet users. This potential is promising for the future of Turkey's e-commerce. The number of internet users increased by $4 \%$ from June 2019 to June 2020. This rate corresponds to 2.4 million people. It is possible to say that Internet users in Turkey are prone to e-commerce. $81 \%$ of internet users between the ages of 16-64 visit online stores at least once a month. $63 \%$ of them shop online at least once a month. The pandemic further increases these rates, and the e-commerce sector in Turkey has doubled its volume in the first six months of 2020. In 2020, the e-commerce sector volume in Turkey reached 91.7 billion $€$ in the first six months. Although general trade in Turkey decreased by $€ 1$ billion from 2019 to 2020, e-commerce has doubled, indicating that consumers in Turkey gravitate towards new consumption habits. These figures show that e-commerce sites should care about the consumption habits of consumers. In this context, researching service dimensions that affect consumers' satisfaction is vital for e-commerce sites (https://www.eticaret.gov.tr/).

A shopping site called hepsiburada.com is one of the sites having the biggest e-commerce market in Turkey. The site has offered online services in Turkey since 2001. It offers its customers over 30 million products in 40 categories. Over 200 million visits are made monthly, and Hepsiburada brings together the businesses, brands, and Turkish products on the platform with the world market through its 'Hepsiglobal' e-export initiative. It was selected as the most popular brand of 2011, 2012, and 2013 and as the e-commerce site of the year in 2013. In addition, Hepsiburada is one of Turkey's most powerful trading platforms (https://www.hepsiburada.com).

While e-commerce volume increases in the world and Turkey every day, service quality perception of customers is increasingly important for e-commerce sites to retain existing customers, regain the lost customers, deepen sales to existing customers and cross-selling, and direct new customers to its website. For this reason, it is essential to investigate to what extent e-service quality is perceived in e-commerce sites, and perceived e-service quality dimensions after-sales affect customer satisfaction.

This study investigates the factors affecting customers' satisfaction shopping from e-commerce sites and the effects of perceived e-service quality and perceived e-service quality after-sales by customers on esatisfaction. Therefore, hepsiburada.com was selected as an example of e-commerce sites operating in Turkey, and a survey is distributed to the customers who purchase goods from this website. This survey aimed to investigate the effects of e-service quality perceived by customers and e-service quality perceived after sales on e-satisfaction. E-S-QUAL scale was used to measure e-service quality, and ERecS-Qual scales were used to measure after-sales e-service quality. These scales are considered to be the most consistent and comprehensive measure of quality in electronic services in the literature (Akınc1, İnan, Aksoy \& Büyükküpçü, 2009; Akınc1, Atılgan-İnan \& Aksoy, 2010).

\section{E-service quality}

The concept of service has entered our lives from the first-day people started serving each other. The service sector started to be seen as an area worth researching scientifically as of the 1940s. Before those years, the concept of service was defined differently by different segments or individuals. While Adam Smith defined service as all activities that do not result in a concrete product, Alfred Marshall defined 
it as the goods that existed when they were created, and Jean-Baptiste Say as all non-manufacturing activities that benefit the products (Bakır, 2017).

Despite many definitions to explain the service, there is no generally accepted standard definition due to the nature of the service sector. Rathmell (1966) expressed this situation by saying that "there are some ideas about what a good is, but when it comes to services, it seems to be understood as everything that is outside of the goods". Furthermore, since the rapidly developing technology will lead to new service branches, it has become challenging to build a consensus on a general definition for service (Rathmell, 1966).

Service quality includes the output resulting from production, how the service is delivered, and how it is delivered. Since services have an abstract structure, service quality also has an abstract structure, which is evaluated chiefly through perceptions. For this reason, the term perceived service quality is often used instead of service quality. Grönroos (1984) considers perceived service quality as an evaluation that emerges from comparing the consumers' expectations about the service with the service they experience. Accordingly, evaluations regarding service quality are formed by comparing a customer's expectations before purchasing the service with the service experienced (Santos, 2003).

Today, the service sector is developing rapidly, and the increase in internet usage accelerates this development. This situation has led to the presentation of information bases on the internet (Çelik \& Sökmen, 2018a). Thus, businesses with solid infrastructures can more easily adapt to the internet environment. In this context, some of the services provided in real life have started to be provided electronically. Therefore, providing services in an electronic environment is called e-service (Lee et al., 2007; Bozbay et al., 2016).

With the emergence of e-service, the term e-service quality has emerged. There are many definitions of e-service quality. Some of these are as follows:

It is an effective marketing tactic that facilitates the distribution and purchase of products and services and the website's efficiency (Zeithaml, Parasuraman \& Malhotra, 2002).

It is a general assessment or judgment of the excellence and quality that consumers make about the eservice provision provided in the virtual environment (Santos, 2003).

It evaluates the service quality offered in the virtual environment by the customers (Lee \& Lin, 2005).

It is a measure for the website to effectively and efficiently facilitate the purchase and distribution of products and services (Parasuraman et al., 2005).

It evaluates how effectively the company performs the sales and distribution of the services over the website and how successful the resulting service output is in meeting customer demands and needs (Çelik \& Başaran, 2008).

E-service quality is an essential strategy for markets that try different services by satisfying consumers, establishing consumer values, and ensuring re-purchasing and consumer loyalty (Ozment \& Morash, 1994). Besides, it is an essential factor in increasing the profitability of businesses and ensuring customer loyalty and satisfaction (Buckley, 2003). E-service quality has increased the importance of fast service providers (servers), databases, and infrastructure consisting of technical personnel (Rayport \& Sviokla, 1994-1995; Pandya \& Dholakia, 2005). On the other hand, e-service quality is a critical factor for ecommerce customers because it is much easier to compare prices and technical features of products online than traditional channels (Santos, 2003). Therefore, companies can differentiate to increase customer satisfaction through e-service quality. In this case, they can build customer loyalty by encouraging customers to shop from their sites again (Zeithaml, 2002).

In e-commerce, losing customers is easy, but gaining them is very challenging. The reason for this is that lost customers can quickly turn to alternative sites and investigate the benefits. Customers gain experience in terms of e-service every passing day. While customers evaluate their shopping experiences, they consider many factors, such as product offers, evaluating products, making purchasing decisions, searching and collecting necessary information, customer service, and return/change of products (Menon, 2018). This situation shows that customers have high sensitivity towards quality. Customers who gain experience in e-service quality motivate e-commerce sites to improve their service quality (Çelik, 2009). For this reason, e-commerce sites should fulfil the requirements of the electronic environment, determine what factors consumers pay attention to, and provide services accordingly (Novak et al., 2000; Collier, 2006; Faiz, 2018). 


\section{Scales used to measure e-service quality}

Various tools and methods have been developed to measure e-service quality based on the applications in different sectors. As in the formation of models related to service quality, dimensions for determining e-service quality or quality levels in e-commerce sites have been investigated in these studies, and scales aiming to measure these dimensions have been developed. In this context, some of the researchers who try to measure the quality level in e-services highlight the appearance of the relevant website (Dabholkar, 1996; Yoo \& Douthu, 2001; Yang et al., 2004), while others focus on the content of the information presented to the consumer on the site (Zeithaml et al., 2000; Madu \& Madu, 2002; Loiacono et al., 2007; Li \& Suomi, 2009). Therefore, many different opinions have been put forward regarding the dimensions of e-service quality. One of the reasons there are so many different ideas is that research is conducted in different sectors, as mentioned above. Therefore, the difference between the research and consumption habits in the research sector emerges as an essential factor here. For example, while the information security infrastructure is ahead of banking services' design dimension or product variety dimension, a fashion shopping site stands out more than the information security infrastructure (Bozbay et al., 2016). Some of the prominent e-service quality scales in the relevant literature are presented below:

SITEQUAL: Yoo \& Donthu (2001) criticized the previous studies by arguing that they were conducted to measure the effectiveness of websites rather than measure service quality, and they did not reflect the consumer perspective. Then they developed the SITEQUAL scale. Another reason for developing the SITEQUAL scale is that the previous studies mainly address the general website quality, and there is no study specifically designed for e-commerce sites. As a result of the research conducted in this context, the SITEQUAL scale consisting of 4 quality dimensions and nine items was developed to measure the quality of e-commerce sites. Dimensions included in the scale are ease of use (ease of searching and using information), aesthetic design (having a good multimedia environment and colourful graphics), processing speed (quickly responding to consumer requests), and security (protection of personal and financial information).

PIRQUAL: Francis and White (2002) developed a PIRQUAL scale to evaluate online consumers' previous online purchasing experiences. The determinants of the scale are website, operating system, delivery, consumer service, and security. The website dimension includes the ease and speed of navigating the site, the promotion of the products on the site, and the site's appearance. Factors such as guiding consumers quickly, being easy and reliable to use the website, and approving orders are included in the operating system dimension. Delivery is about delivering the product in the right conditions and on time. Consumer services need to be easy, fast, and personalized. Finally, the security dimension reflects consumers' credit cards and personal information (Francis, 2007).

WEBQUAL: Barnes and Vidgen (2002) developed the WEBQUAL scale to evaluate the perceived service quality of online bookstores such as IBS, BOL, and Amazon in the USA. The dimensions of WEBQUAL are

- Usability (design and usability)

- Information quality (accuracy and reliability of information)

- Service interaction quality (trust and empathy)

The WEBQUAL scale has been deemed more appropriate for designing the best website for users than measuring service quality (Barnes et al., 2001; Zeithaml, Parasuraman, Malhotra, 2002; Akın \& Toksarı, 2017).

WEBQUALTM: It was developed by Loiacono et al. (2002). The simple idea behind WebqualTM is to predict the behaviour of consumers when they revisit the site based on the overall perception of the quality of the website. The WEBQUALTM scale, created due to the study conducted with students, consists of 36 items, including 12 quality dimensions and three items in each dimension. Items included in the scale are:

- Easy to understand: It is easy to read and understand the content of the website.

- Information fit for purpose: The information on the site is sufficient, complete, and up to date.

- Interaction: Two-way communication between consumer and business.

- Trust: Confidentiality of the information and secure communication.

- Response time: The reaction time to the processor requests performed.

- Intuitive operations: Quickly navigating and operating on the site. 
- Visuality: The aesthetic appearance of the website.

- Innovation: The uniqueness and degree of creativity of the site design.

- Emotional attraction: The emotional impact of using the site on the user.

- Online integrity: Providing the user with access permissions for the necessary actions.

- Advantages compared to alternative channels: The website being more attractive than other channels to contact the business.

- Consistent image: The website works in coordination with other communication channels belonging to the company and is consistent.

eTailQ: Wolfinbarger and Gilly (2003) developed the eTailQ scale to measure the quality of the services offered by retail companies on their websites. eTailQ scale consists of 4 quality dimensions and 14 items. The quality dimensions of the eTailQ scale are website design, customer service, privacy/security, and reliability. The site design includes all elements such as navigation, information search, ordering, personalization of the website. Customer service means that the website responds quickly to consumer requests and is relevant and helpful in solving problems. Finally, while confidentiality includes sharing information and the security of payment information, reliability includes the correct presentation and smooth delivery of products (Wolfinbarger \& Gilly, 2003).

E-S-QUAL: It was developed by Parasuraman et al. (2005). SERVQUAL is the first study investigating the strengths and weaknesses of companies in terms of overall service quality (Parasuraman et al., 1988). However, the SERVQUAL service quality scale consists of standard services quality dimensions such as ability, courtesy, cleanliness, comfort, and looking friendly, which are unimportant in the internet environment and is not related to critical internet services quality dimensions such as accessibility, communication, compensability, and appearance (Connolly et al., 2010). Therefore, the necessity for better evaluation of e-service quality has emerged. First, Zeithaml et al. (2002), inspired by SERVQUAL, developed the E-S-QUAL scale. However, this scale, like other similar e-service quality studies, focused only on the behaviour of consumers while shopping online and ignored their pre-sales behaviour. Later, Parasuraman et al. (2005) updated their traditional SERVQUAL studies to measure e-service quality and finalized their scales with E-S-QUAL, the electronic service quality study. Accordingly, the E-SQUAL service quality scale of Parasuraman et al. (2005) consists of 4 dimensions:

1. Efficiency is defined as the speed and ease of connecting to a site (Parasuraman et al., 2005). The primary purpose for consumers to shop online is the power and time offered by the internet (Kim et al., 2006). In this context, the website's ease of use and speed is essential dimension in measuring e-service quality.

2. System Availability: It is the dimension related to the correct functioning of functions such as the links and buttons of the website (Parasuraman et al., 2005). Consumers do not want to encounter interruptions, broken links, and site crashes on a website.

3. Fulfilment: It is a process that involves a site having the products and services we are looking for and delivering the products/services we buy safely within the promised timeframe (Zeithaml et al., 2002; Parasuraman et al., 2005). In this context, it is one of the critical factors in evaluating the service quality of a website.

4. Privacy: It is the dimension related to protecting and securing the site's customer information (Wolfinbarger \& Gilly, 2003; Parasuraman et al., 2005). The reason why many people feel uneasy about shopping online is such concern. In this context, the privacy/security principle plays a significant role in the overall quality of the site and in stimulating the purchasing impulse of customers (Loiacono et al., 2002; Boshoff, 2007).

E-RecS-Qual: Parasuraman et al. (2005) mention the dimensions that should be present on the site to increase the consumers' quality perceptions when they have a problem with the website or when they ask a question to the business, that is, in an extraordinary situation. The scale consists of 3 dimensions and 11 statements. These are:

Responsiveness: It expresses the willingness of the website to deal with the issue when consumers experience any problems,

Contact: It means that consumers can reach the website by phone or through online representatives.

Compensation: It refers to the degree to which the website compensates consumers for their problems. 


\section{E-satisfaction}

Satisfaction, which is at the centre of modern marketing practice and considered as the most crucial output, is a concept that serves as a bridge in the connection of post-purchase attitude change, repeat purchasing, and brand dependency with purchasing processes (LaTour \& Peat, 1979; Churchill \& Surprenant, 1982; Yi, 1989). Etymologists state that the word satisfaction is derived from the Latin roots satis (sufficient) and facere (to achieve). In simple terms, considering the roots of the word, the basic definition of product or service satisfaction is providing the point where competence is sought (Altunışık et al., 2010). Oliver $(1980,1997)$ introduced the most widely accepted definition of satisfaction in the literature. He defined expectation as a component that constitutes a reference point in the judgment of satisfaction and is expressed as the primary component of satisfaction. Many quantitative studies (Oliver 1980; Bearden \& Teel 1983; Labarbera \& Mazursky 1983; Cadotte et al. 1987) supported Oliver's approach.

Although profitability seems to be the essential factor for businesses, the extent to which businesses satisfy their customers and to what extent they create a sense of loyalty in customers determines their future. For this reason, businesses have to consider their customers at the centre of their activities to retain existing customers, find new customers, and regain old customers. Especially with the easy and fast access of the internet to information, a business that produces services in today's world has to ensure customer satisfaction (Wu, 2006; Saydan, 2010, Çelik \& Sökmen, 2018b). It should also be noted that customer satisfaction is not a universal concept. Customer satisfaction includes subjective criteria that vary according to the customer, and it is not expected that every customer will evaluate the same service according to the same criteria and show the same satisfaction (Jaiswal et al., 2010; Faiz, 2018).

Szymanski \& Hise (2000) were the first researchers who studied the concept of satisfaction in the electronic environment. E-satisfaction (electronic satisfaction), a new concept in the literature, aims to determine the components that affect consumer satisfaction in the internet environment. As a result of the data collected with qualitative techniques and the analysis of the conceptual model revealed, it was stated that four factors, namely site design, convenience, sales development (product information), and financial security, were influential on satisfaction.

As marketers know the importance of satisfaction, satisfaction is always at the centre of the marketing concept. The perceived e-service quality is of great importance, especially for e-commerce sites in meeting these expectations. The customer goes to the purchasing stage, believing in the general service quality offered by the website. He/she measures the value obtained in return for this process and determines the level of satisfaction. Therefore, customer satisfaction is accepted as a vital factor in the website's survival, profitability, and development (Hou, 2005; Jones et al., 2010).

The emergence of e-satisfaction depends on the effect of e-service quality elements. E-service quality elements are a process determined by revealing the customer's reaction during and after shopping (Bozbay et al., 2016). If performance meets or exceeds expectations, satisfaction occurs, while if performance falls short of expectations, dissatisfaction will occur, and customers will probably seek alternative businesses (Kotler \& Keller, 2006).

Creating customer satisfaction provides businesses with advantages such as positive word of mouth, retaining existing customers, and gaining new customers. $90 \%$ of the unsatisfied customers can finish with the business. While customers share this dissatisfaction with at least ten people, they share their satisfaction with relatively fewer people. According to the 3-33 rule obtained from a study, 33 people are ready to tell others about their negative experiences compared to 3 people who are ready to tell others about their positive experiences (Özgüven, 2008). For this reason, the higher the perceived eservice quality and after-sales e-service quality, especially in e-commerce, the more satisfied the customers will be, and they will provide businesses with new customers by sharing these experiences with their environment.

\section{Research}

In this section, firstly, the proposed model and research hypotheses are mentioned. The following includes empirical methodology. The rest of the section is devoted to the research findings, and these findings are interpreted.

\section{Proposed model and research hypotheses}

The purpose of the research model created in the light of the information obtained from the literature is to determine how the concepts of e-service quality and after-sales e-service quality affect customer satisfaction in e-commerce sites. Figure 1 shows the proposed research model. 


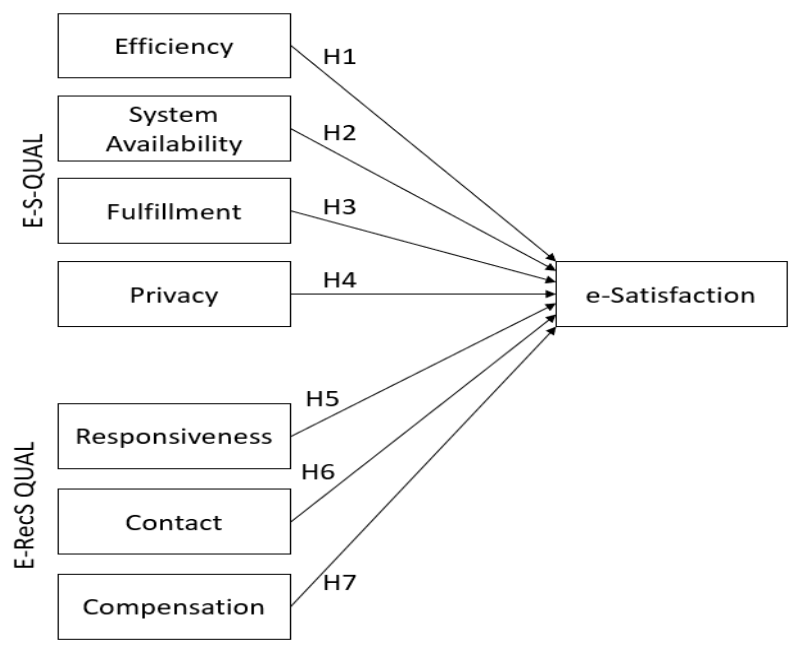

Figure 1: Proposed Research Model

Services have a distinctive feature from other products in that they are intangible. Considering this feature, the benefit provided to and perceived by the consumer emerges from the service. Transfer of services to electronic media is called electronic service (e-service) (Bozbay et al., 2016). Unlike traditional services, e-services help businesses and marketing managers understand what their customers value in their electronic shopping and develop strategies. Selling products only through online environments is not enough. It is also necessary to provide a level of service quality that can meet the expectations and demands of customers (İter, 2009: 99).

In this study, E-S-QUAL and E-RecS-QUAL scales were used to measure the effect of service quality on e-satisfaction in e-commerce sites. E-S-QUAL is accepted as an essential scale for e-service quality. In addition, E-RecS-QUAL is used to measure after-sales e-service quality (Ulkhaq et al., 2017).

The E-S-QUAL scale is the major scale used to measure e-service quality and evaluates consumers' data with 22 questions collected in four different dimensions. These dimensions are (1) efficiency: expressions that measure the ease and speed of accessing and using the e-commerce site, (2) fulfilment: expressions that measure the degree of fulfilment of the e-commerce site's commitments regarding product availability and shipping, (3) system availability: statements about the technical functionality of the e-commerce site, (4) privacy: the security of the e-commerce site and the degree of protection of customer information, and related questions (Parasuraman et al., 2005).

Akınc1 et al. (2010) stated in their study on internet banking that the efficiency, system availability, fulfilment, and privacy components of the E-S-QUAL scale affect the perceived value. In their study using the ES-QUAL scale, Kim and Kim (2010) found that the dimensions of effectiveness and privacy significantly affected the e-satisfaction of the participants in both the United States and South Korea, on the other hand, the system availability and transaction processing dimensions were only effective in South Korea. According to Durmuş et al. (2015), the effectiveness (efficiency) dimension of e-service quality affects the e-satisfaction of the participants. Güllülü et al. (2016) stated in their study that 'the fulfilment dimension has the most effect on perceived value, while privacy is the most effective dimension on consumers' loyalty intention and average quality. Karadeniz and Çuhadaroğlu (2016) examined the dimensions of mobile service quality using the variables in the E-S-QUAL scale. As a result, they concluded that all service quality dimensions are practical on customer satisfaction and that trust and sensitivity dimensions are effective in satisfaction. Akın and Toksarı (2017) found that the relationship between e-loyalty and effectiveness, one of the service quality dimensions, is solid, while the relationship between e-loyalty and privacy is weak. Ates (2017) stated that the security and customer relations dimensions of e-service quality positively affect e-satisfaction. Düger and Kahraman (2017) stated that e-service quality has a positive effect on e-satisfaction. Faiz (2018) revealed that e-service quality has a positive and significant effect on e-satisfaction and e-loyalty.

In addition, the dimension of fulfilment, one of the dimensions of e-service quality, has more explanatory power than other dimensions. Erçetin and Arıkan (2020) found that all of the e-service quality dimensions had a positive effect on e-satisfaction. Leonnard (2019) found that efficiency and fulfilment significantly affect e-satisfaction. It also concluded that fulfilment and privacy significantly affect e-trust. Ahmed et al. (2020) investigated the satisfaction of online bank customers using the E-SQUAL scale. They concluded that E-S-QUAL dimensions have a positive and robust effect on customer satisfaction. Ridwandono et al. (2020) found that efficiency, system availability, fulfilment, and privacy 
significantly affect perceived value. In their study on e-service quality and trust in mobile application user satisfaction, Söylemez and Karahan (2020) concluded that the effectiveness factor and trust variable, which are sub-dimensions of e-service quality, have a significant effect on e-satisfaction. They also found that the effect of mobile application satisfaction and trust on mobile application purchase intention is significant. Alotaibi (2021) determined that fulfilment has a significant and positive effect on e-satisfaction, while efficiency and privacy do not affect e-satisfaction. Yellaturu et al. (2021), in their research on libraries in India, conducted a study using the E-S-QUAL scale. They concluded that the fulfilment and privacy variables significantly affect the service quality, while the efficiency and system availability variables did not significantly affect it. Based on these studies, the hypotheses $\mathrm{H} 1, \mathrm{H} 2, \mathrm{H} 3$, and $\mathrm{H} 4$ were formed to test the relationships between efficiency, system availability, fulfilment and privacy, and e-satisfaction variables.

H1: Efficiency has a significant and positive effect on e-Satisfaction.

H2: System Availability has a significant and positive effect on e-Satisfaction.

H3: Fulfillment has a significant and positive effect on e-Satisfaction.

H4: Privacy has a significant and positive effect on e-Satisfaction.

E-RecS-QUAL, which is the secondary scale used to determine e-service quality, measures the improved performance of e-commerce sites in three dimensions: (1) Responsiveness: Expressions about effectively solving problems of and returns from customers; Compensation: Statements of customers experiencing problems regarding the compensation performance; Contact: statements about online support or telephone helpline (Parasuraman et al., 2005).

Akıncı (2006) applied E-S-Qual and E-RecS-Qual scales on Internet banking services. This study concluded that the dimensions that most affect the perceived value are efficiency, transaction performance, confidentiality, and system compliance. Akınc1 et al. (2010) stated in their study on internet banking that the responsiveness and compensation components of the E-RecS-QUAL scale affected commitment. Durmuş et al. (2015) proposed a model investigating the e-service quality dimensions that affect customer satisfaction and purchase intention using the E-S-QUAL and E-recSQUAL scales. They tested this model with a repeated longitudinal survey in 2012 and 2014. In the data collected in 2012, "electronic efficiency" was a significant dimension that provides customer satisfaction by determining e-service quality in private purchasing decisions, while 2014 data showed that the "electronic contact" factor was added to the model as a significant variable. According to Sharifah Latifah Binti Syed A. Kadir (2018), the government in Malaysia aimed to investigate the service quality problems of the new application developed to provide better online services to increase the government's credibility. The questionnaire distributed to 400 respondents explores e-procurement portal/websites using quality of service (ES-QUAL) and e-recovery quality of service (E-RecSQUAL) scales. The collected data was analyzed using Smart PLS 3.0 to test the relationships between the dimensions of efficiency, system availability and privacy, activity and communication. The study's findings showed that both E-S-QUAL and E-RecS-QUAL dimensions strongly affect perceived service quality and behavioural intentions. Ridwandono et al. (2020) found that the responsiveness dimension significantly affects the perceived value, while the compensation and contact have no significant effect. Alotaibi (2021) revealed that responsiveness, compensation, and contact have a significant and positive effect on e-satisfaction. Based on these studies, H5, H6, and $\mathrm{H} 7$ hypotheses were formed to test the relationships between responsiveness, contact, compensation, and e-satisfaction variables.

H5: Responsiveness has a significant and positive effect on e-Satisfaction.

H6: Contact has a significant and positive effect on e-Satisfaction.

H7: Compensation has a significant and positive effect on e-Satisfaction.

\section{Data collecting}

The data used to test the research model was obtained from the customers of the hepsiburada.com ecommerce site. First of all, the research participants were asked whether they shopped on the whole page of hepsiburada.com. Then, the users who stated that they shopped were filled out with a questionnaire. Thus, a comprehensive questionnaire was created. It indicated the study's purpose and the researchers' names and included demographic information, e-service quality, after-sales e-service quality, and e-satisfaction scales. The survey was created through Google Forms, and a survey link was obtained. This questionnaire link was delivered to the participants through different electronic communication means. Data were collected between March and May 2019. Ethics committee permission 
was not needed as the data were collected before January 1, 2020. As a result, survey data were collected from 417 participants $(\mathrm{N}=417)$.

Table 1: Demographic Distribution of Participants

\begin{tabular}{|c|c|c|c|}
\hline & & Frequency & Percentage \\
\hline \multirow{2}{*}{ Gender } & Female & 232 & 55.6 \\
\hline & Male & 185 & 44.4 \\
\hline \multirow{5}{*}{ Age } & Between 18 and 25 & 43 & 10.3 \\
\hline & Between 26 and 35 & 244 & 58.5 \\
\hline & Between 36 and 45 & 53 & 12.7 \\
\hline & Between 46 and 55 & 38 & 9.1 \\
\hline & 56 or over & 39 & 9.4 \\
\hline \multirow{2}{*}{ Marital Status } & Married & 211 & 50.6 \\
\hline & Single & 206 & 49.4 \\
\hline \multirow{4}{*}{ Education } & High School & 35 & 8.4 \\
\hline & Associate Degree & 51 & 12.2 \\
\hline & Bachelor's Degree & 254 & 60.9 \\
\hline & Postgraduate & 77 & 18.5 \\
\hline \multirow{5}{*}{ Monthly Income } & 0-1000€ & 36 & 8.6 \\
\hline & 1001£-3000€ & 58 & 13.9 \\
\hline & 3001€-6000€ & 185 & 44.4 \\
\hline & 6001£-10000€ & 89 & 21.3 \\
\hline & $10000 €$ or more & 49 & 11.8 \\
\hline \multirow{5}{*}{$\begin{array}{l}\text { The average number of } \\
\text { purchases per year from this } \\
\text { site }\end{array}$} & Less than 6 & 101 & 24.2 \\
\hline & Between 6 and 10 & 266 & 63.8 \\
\hline & Between 11 and 15 & 26 & 6.2 \\
\hline & Between 16 and 25 & 12 & 2.9 \\
\hline & More than 25 & 12 & 2.9 \\
\hline \multirow{5}{*}{ Most shopping category } & Electronic & 206 & 49.4 \\
\hline & Clothes & 99 & 23.7 \\
\hline & Cosmetic & 37 & 8.9 \\
\hline & Accessory & 16 & 3.8 \\
\hline & Others & 59 & 14.2 \\
\hline Total & & 417 & 100 \\
\hline
\end{tabular}

Table 1 shows the frequency-percentage distributions of the demographic data of the individuals participating in the study. Accordingly, 55.6\% of the participants are women $(\mathrm{n}=232)$ and $44.4 \%$ are men $(n=185) .10 .3 \%(n=43)$ of the participants are in the $18-25$ age group, $58.5 \%(n=244)$ in the $26-35$ age group, $12.7 \%(n=53)$ in the $36-45$ age group, $9.1 \%(n=38)$ were in the $46-55$ age group, and $9.4 \%$ were 56 years and above. In terms of marital status, $60.6 \%(n=211)$ of the participants are married and $49.4 \%$ $(n=206)$ are single. $8.4 \%(n=35)$ of the participants are high school graduates, $12.2 \%(n=51)$ associate degree graduates, $60.9 \%(n=254)$ undergraduate graduates, and $18.5 \%(n=77)$ postgraduates. According to their monthly income, $8.6 \%(\mathrm{n}=36)$ of the participants have monthly income between $0-1000 \mathrm{f}, 13.9 \%$ $(n=58)$ between $1001 £-3000 €, 44.4 \%(n=185)$ between $3001 €-5000 €, 21.3 \%(n=89)$ between $6001 €-10000$ $€$, and $11.8 \%(\mathrm{n}=49)$ gain $10000 €$ or more. When the average number of purchases of the participants annually from this site is examined, $24.2 \%$ of the participants $(n=101)$ shop less than 6 times, $63.8 \%$ $(n=266) 6$ to 10 times, $6.2 \%(n=26) 11$ to 15 times, 2.9\% $(n=12) 16$ to 25 times, and $2.9 \%(n=12)$ shop more than 25 times. When the category with the most shopping was examined, $49.4 \%(n=206)$ of the participants shop from the electronics category, $23.7 \%(n=99)$ from clothes, $8.9 \%(n=37)$ from cosmetics, $3.8 \%(n=16)$ from accessories, and $14.2 \%(n=59)$ of them shop from other categories. 


\section{Scales}

The scales used in this study were obtained by adapting from previous studies on this subject. Answers were taken with a 5 -point Likert scale. ( $1=$ Strongly Disagree, 5 = Strongly Agree). E-S-QUAL and ERecS-QUAL scales were used to measure the concepts of e-service quality and after-sales e-service quality. The E-S-QUAL scale consists of 14 statements, the E-RecS-QUAL scale consists of 11 statements, and customer satisfaction consists of 8 statements (Parasuman et al., 2005).

The original forms of the scales were translated from English to Turkish in two stages. First, two academicians and two translation experts who have a good command of English independently translated all scales into Turkish. In the next stage, the translations were compared by a researcher and a translation expert, and the translations considered to be the best were accepted. Finally, the scale expressions were finalized after rechecking by two academicians who are experts in their field.

\section{Data analysis and findings}

The R program created demographic information, confirmatory factor analysis, and structural equation model analysis. The use of the $\mathrm{R}$ program in analyzes is due to its robust infrastructure in statistical analysis and its free-of-charge availability (Çelik et al., 2018). SPSS 18 program was used to measure the reliability of the scales and to create the correlation matrix.

Demographic data were analyzed in the first stage. Table 1 presents the relevant findings. Then, the goodness of fit values was obtained by performing confirmatory factor analysis. The goodness of fit indices examined in the study is Chi-square fit test/degree of freedom, CFI (Comparative Fit Index), RMSEA (Root Mean Square Error of Approximation), TLI (Tucker-Lewis Index), RNI (Relative Noncentrality Index), NNFI (Non-Formed Fit Index), and IFI (Incremental Fit Index).

Table 2: Values of the Goodness of Fit

\begin{tabular}{|l|l|l|l|l|}
\hline Fit index & Value & Good fit values & Acceptable fit values & Result \\
\hline Chi square/df & $2053.914 / 671=3.06$ & $<3$ & $<5$ & Acceptable \\
\hline CFI & 0.917 & $>0.95$ & $>0.90$ & Acceptable \\
\hline RMSEA & 0.070 & $<0.050$ & $<0.080$ & Acceptable \\
\hline TLI & 0.908 & $>0.95$ & $>0.90$ & Acceptable \\
\hline RNI & 0.917 & $>0.95$ & $>0.90$ & Acceptable \\
\hline NNFI & 0.908 & $>0.95$ & $>0.90$ & Acceptable \\
\hline IFI & 0.917 & $>0.95$ & $>0.90$ & Acceptable \\
\hline
\end{tabular}

Table 2 shows the goodness of fit values for the study. When the findings are examined, it is seen that all values of the goodness of fit show an acceptable fit. This situation indicates that the data collected with the proposed model are compatible.

Table 3 shows the Cronbach Alpha Reliability Coefficient, AVE (Average Variance Extracted), CR (Composite Reliability), and correlation matrix of all scales. Accordingly, the Cronbach Alpha coefficient of all scales is between 0.968 and 0.815. It is accepted in the literature that the Cronbach Alpha reliability coefficient should be higher than 0.7 (Nunally, 1978; Iacabucci \& Duhackek, 2003). Thus, the reliability of the scales is relatively high.

AVE must be greater than 0.5, and CR must be greater than AVE for convergence validity (Hair et al., 2010; Fornell \& Larcker, 1981). As seen in Table 3, AVE values are between 0.580 and 0.797 . Therefore, all values are higher than 0.50 . Also, CR values of all structures are more significant than AVE. This finding shows that the scales are valid. 
Table 3: Cronbach's Alpha, AVE, CR Values, and Correlation Matrix

\begin{tabular}{|c|c|c|c|c|c|c|c|c|c|c|c|}
\hline & $\alpha$ & AVE & CR & 1 & 2 & 3 & 4 & 5 & 6 & 7 & 8 \\
\hline 1-EFF & 0.910 & 0.580 & 0.906 & 1 & & & & & & & \\
\hline 2-SA & 0.941 & 0.696 & 0.941 & $0.664^{* *}$ & 1 & & & & & & \\
\hline 3-FUL & 0.855 & 0.601 & 0.853 & $0.583^{* *}$ & $0.764^{\star *}$ & 1 & & & & & \\
\hline 4-PR & 0.902 & 0.759 & 0.904 & $0.549^{* *}$ & $0.540^{* *}$ & $0.606^{* *}$ & 1 & & & & \\
\hline 5-RES & 0.941 & 0.765 & 0.942 & $0.679^{* *}$ & $0.666^{* *}$ & $0.655^{* *}$ & $0.633^{* *}$ & 1 & & & \\
\hline $6-\mathrm{CON}$ & 0.875 & 0.712 & 0.881 & $0.550^{* *}$ & $0.609^{* *}$ & $0.565^{* *}$ & $0.583^{\star *}$ & $0.746^{* *}$ & 1 & & \\
\hline 7-COM & 0.815 & 0.698 & 0.821 & $0.399^{* *}$ & $0.407^{* *}$ & $0.394^{* *}$ & $0.483^{* *}$ & $0.609^{* *}$ & $0.683^{* *}$ & 1 & \\
\hline 8-SAT & 0.968 & 0.797 & 0.969 & $0.664^{* \star}$ & $0.677^{* *}$ & $0.663^{* \star}$ & $0.592^{\star *}$ & $0.800^{* *}$ & $0.687^{* *}$ & $0.646^{\star *}$ & 1 \\
\hline \multicolumn{12}{|c|}{$\begin{array}{l}\text { a: Cronbach Alpha Coefficient; AVE: Average Variance Extracted; CR: Construct Reliability; EFF: Efficiency; SA: System } \\
\text { Availability; FUL: Fulfillment; PR: Privacy; RES: Responsiveness; CON: Contact; COM: Compensation; SAT: e-Satisfaction } \\
{ }^{*} \text { p }<0.01\end{array}$} \\
\hline
\end{tabular}

Correlation analysis was conducted to show the relationships between variables. According to the analysis, there is a significant $(\mathrm{p}<0.01)$ and positive relationship between all variables. The most vital relationship between structures was between e-Satisfaction and Responsiveness ( $r=0.800, p<0.01)$, and the weakest relationship were between Fulfillment and Compensation $(r=0.394, p<0.01)$.

Table 4: Structural Equation Model Analysis

\begin{tabular}{|l|l|l|l|}
\hline Hypothesis & $\begin{array}{l}\text { Standardized } \\
\boldsymbol{\beta}\end{array}$ & $\mathbf{p}$ & Support / Rejection \\
\hline $\begin{array}{l}\text { H1: Efficiency has a significant and positive } \\
\text { effect on e-Satisfaction. }\end{array}$ & -0.004 & 0.963 & Rejected \\
\hline $\begin{array}{l}\text { H2: System Availability has a significant and } \\
\text { positive effect on e-Satisfaction. }\end{array}$ & 0.301 & 0.002 & Supported \\
\hline $\begin{array}{l}\text { H3: Fulfillment has a significant and positive } \\
\text { effect on e-Satisfaction. }\end{array}$ & 0.161 & 0.002 & Supported \\
\hline $\begin{array}{l}\text { H4: Privacy has a significant and positive effect } \\
\text { on e-Satisfaction. }\end{array}$ & -0.045 & 0.317 & Rejected \\
\hline $\begin{array}{l}\text { H5: Responsiveness has a significant and } \\
\text { positive effect on e-Satisfaction. }\end{array}$ & 0.455 & 0.000 & Supported \\
\hline $\begin{array}{l}\text { H6: Contact has a significant and positive effect } \\
\text { on e-Satisfaction. }\end{array}$ & -0.223 & 0.008 & Rejected \\
\hline $\begin{array}{l}\text { H7: Compensation has a significant and } \\
\text { positive effect on e-Satisfaction. }\end{array}$ & 0.403 & 0.000 & Supported \\
\hline
\end{tabular}

Table 4 shows the hypotheses supported and rejected as a result of the structural equation model analysis. Accordingly, H2, H3, H5, H7 were supported, H1, H4, H6 were rejected.

Figure 2 shows coefficients between variables $\left({ }^{* *} \mathrm{p}<0.05,{ }^{* * *} \mathrm{p}<0.001\right)$ and $\mathrm{R}^{2}$ value. Accordingly, satisfaction $\left(R^{2}=0.80\right)$ is explained $80 \%$ by efficiency, system availability, fulfilment, privacy, responsiveness, contact, and compensation. While satisfaction was explained $80 \%$ by these variables $\left(\mathrm{R}^{2}=0.80\right)$, it was explained $20 \%$ by different variables. 


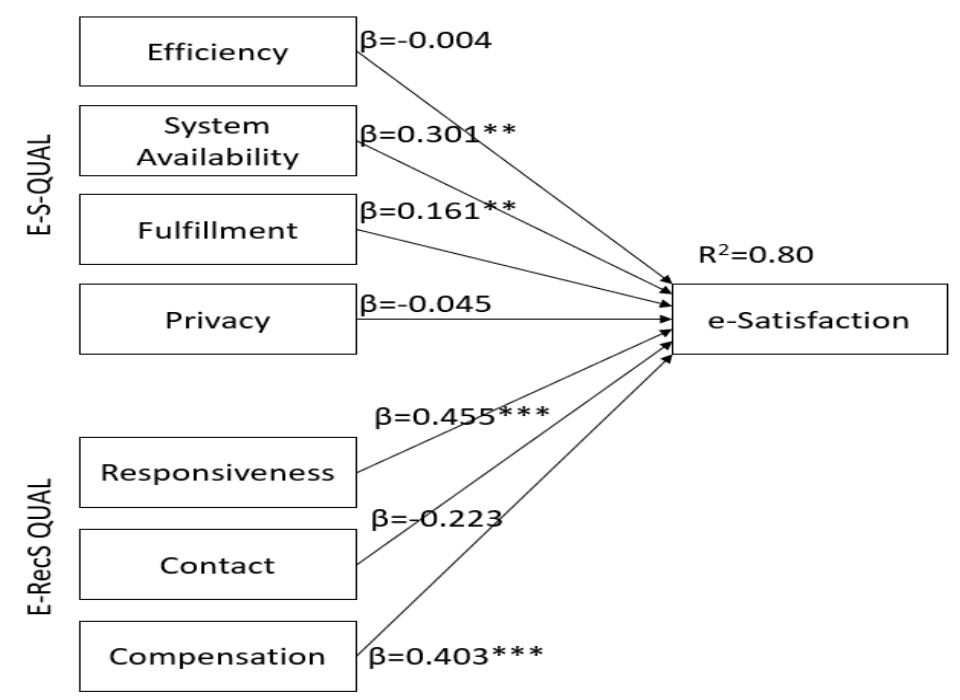

Figure 2: Path Analysis

\section{Conclusions and discussion}

Businesses have started to carry out their commercial activities in electronic environments with the emergence of electronic commerce. The diversification of the products/services offered to consumers in the electronic environment and the increase in the number of businesses in this field make it essential to produce quality service. Thanks to technology, consumers can compare the product/service they purchase from any business in an electronic environment with another business, and if they do not find it quality, they can purchase service from another business. That is why it becomes essential for businesses to provide services by fulfilling the requirements of the electronic environment and by determining what factors consumers pay attention to (Faiz, 2018). The quality elements sought by the consumers in the services provided in traditional environments differ from the quality understanding of the consumers in online environments. For this reason, it is crucial to measure the quality of the service that businesses provide on the internet.

Businesses turned to new searches and marketing tactics because of the increasing competition in today's world. Primarily, an e-commerce that provides a great advantage to businesses seeking a competitive advantage directed them in this direction. For this reason, creating satisfied customers, which is the primary purpose of marketing, became more critical for e-commerce sites. Businesses need to retain existing customers and direct new customers to the website. A business that uses e-commerce effectively can respond quickly to its customers, improve its service quality, increase operational efficiency, reduce costs, and increase satisfaction. Besides, because e-commerce sites are suitable for comparison, customers are now more sensitive about e-service quality. In this context, investigating to what extent e-service quality and after-sales e-service quality affect satisfaction for e-commerce sites is now ever more critical.

This study aims to observe the effect of the e-service quality and after-sales e-service quality of the ecommerce site hepsiburada.com on satisfaction by using e-service quality (ES-QUAL) and postshopping e-service quality (E-RecS-QUAL) scales. The collected data were tested by structural equation model analysis in the light of the relevant literature and similar studies.

According to the results obtained, efficiency, one of the e-service quality dimensions, has no significant effect on e-satisfaction. This finding is contrary to that of some studies in the literature (Kim \& Kim, 2010; Durmuş, et al., 2015; Bozbay et al., 2016; Erçetin \& Arıkan, 2020). The finding is probably because computer and internet use became more widespread in Turkey. Thus, the digital literacy of users improves, and they can quickly adapt to new technologies. On the other hand, as e-commerce sites are increasing daily, users can easily navigate e-commerce sites, find the products they need and perform their transactions quickly. Also, because e-commerce sites are increasingly similar and meet specific standards, a user who uses an e-commerce site can easily find what he/she is looking for when he/she enters another e-commerce site. These factors show that the efficiency dimension does not affect esatisfaction. 
System availability, another e-service quality dimension, has a significant and positive effect on esatisfaction. This result is similar to that of many studies (Kim \& Kim, 2010; Arslan, Atalık, 2016; Durukal, et al., 2019; Faiz, 2018; Erçetin \& Arıkan, 2020; Yıldız, 2020). This finding is related to the desire of today's e-commerce customers to receive fast and timely service. If the website he/she wants to shop from is unready for use or opens slowly, the customer will be discontented with this situation. When he/she experiences a delay, he/she will turn to the alternative website if available. Also, users will experience dissatisfaction if the site crashes during shopping or after the order information is saved. In this context, e-commerce sites must provide uninterrupted service. For this, even when the traffic density is high, the site's infrastructure must handle it. It is vital that the website has a sufficient number of trained workforce in this area and that they intervene immediately in case of a problem.

The fulfilment dimension, one of the e-service quality dimensions, has a significant and positive effect on e-satisfaction. The same finding was found in some studies in the literature (Kim \& Kim, 2010; Ding et al., 2011; Rafiq et al., 2012; Güllülü, 2016, Doğan \& Burucuoğlu, 2018; Faiz, 2018; Rita et al., 2019; Erçetin \& Arıkan, 2020). Accordingly, e-commerce sites must keep their promises for shopping and afterwards, offer the products they can supply, pack them well within the promised time, and deliver them correctly to ensure the satisfaction of their customers. Also, customers need to deliver their orders quickly and resolve consumer problems quickly. Delivery of products days or weeks after payment on e-commerce sites increases the importance of the fulfilment dimension on customer satisfaction. Besides, e-commerce sites need to have a distribution network to deliver their orders quickly and reliably. Investments in this context will result in greater consumer satisfaction.

One of the most exciting results of the research is that the privacy dimension, one of the e-service quality dimensions, has no significant effect on e-satisfaction. This finding is the opposite of many studies in the literature (Yoo \& Donthu, 2001; Şenel et al., 2012; Bozbay et al., 2016; Yaşin et al., 2017; Durukal et al., 2019; Faiz, 2018). The privacy dimension is about protecting personal information, storing credit card information, and keeping the behaviour patterns within site. Privacy has always been an essential element in influencing consumer behaviour. In an uncertain environment such as Internet-based ecommerce transactions, the issue of privacy becomes even more critical. The key to success in ecommerce sites depends on consumers' feeling safe while shopping. Therefore, E-commerce sites should specify what information is collected from users and how this information will be used within the scope of their privacy policies. Also, prior consent should be obtained from the consumers for potential personal data transfers, and how to contact the consumer for relevant information sharing should be declared. The sample of this study is the customers of hepsiburada.com. The findings show that the site convinced its users that they will fully protect customer information by providing a reliable environment and that the information obtained will remain confidential. Users who are convinced of this stated that the privacy dimension does not affect e-satisfaction.

On the other hand, the dimension of privacy can be regarded as a factor that should be defined and protected by laws today. The privacy-related features of Hepsiburada.com have become an industrystandard rather than a feature, which has been influential in the emergence of this result. In addition to these, increasing security measures, new payment methods (virtual credit cards, secure internet banking, 3D secure system, e-wallet applications, cash on delivery, mail order, e-cash, electronic money, smart card, electronic check, etc.), consumer testimonials or reviews, recommendations of reference groups, and money-back guarantees ensure that customers feel safe. Also, hepsiburada.com ecommerce site, as a website with a serious and professional corporate identity image in Turkey, is believed to give confidence to consumers in terms of privacy.

Responsiveness, one of the dimensions of e-service quality after shopping, is the most effective dimension of e-satisfaction. When customers encounter a problem after purchasing a product, taking into account and resolving it quickly, on time, and easily is the most effective dimension for esatisfaction. The warranty conditions provided by the site must protect the customer's rights. If the product is returned, the customer should be offered a product exchange, refund, or shopping check. The customer should be able to choose the option he/she wants among these options. In e-commerce, because customers shop without seeing and touching the products, there may be a difference between their expectations and the product they receive after shopping. Companies should share their product information in detail on their websites to prevent this situation.

On the other hand, while e-commerce develops very rapidly, the number of shopping done every day and the problems encountered increase. Shopping sites need to employ sufficient personnel to make a fast reply to their customers. A separate department should be created for product returns, and this department should reply to customer requests in 7 days and 24 hours and finalize them. The authorities reached by customers must have sufficient knowledge and authority to solve customers' problems. 
When a sufficient number of employees work, sites will provide better quality service to their customers. Moreover, customer satisfaction will increase.

Contact dimension, another dimension of e-service quality after shopping, has no significant effect on e-satisfaction. This finding is explained by the available contact information of e-commerce sites on their site today. Finding no effect of contact dimension on e-satisfaction is because this is not a feature anymore but a standard feature. On the other hand, this study was conducted for the users of Hepsiburada.com. This e-commerce site satisfies consumers in terms of communication because it has a serious and professional corporate identity in Turkey.

It has been determined that the compensation dimension, one of the dimensions of e-service quality after shopping, is the second most compelling dimension of e-satisfaction. It is essential that when customers who decide to purchase products from e-commerce sites with no opportunity to control, try, or touch are sent a product that they are not satisfied with, it is compensated by the site officials. When the customer wants to return the product he/she bought from the e-commerce site, the product must be received by the shipping company from the customer's home or workplace. Also, when the customer experiences any damage related to his product, the company must compensate for this loss. Since the satisfaction level of the compensated customers will increase, it is expected that the commercial relationship established with the website will be longer, and customer loyalty will increase.

\section{Recommendations}

\section{Recommendations for future research}

The research was carried out with customers who shop on hepsiburada.com. It may be helpful to repeat the research with customers who shop from other e-commerce sites and compare the results. Considering possible differences, it will be possible to increase customer satisfaction by providing more effective e-service quality and after-sales e-service quality.

\section{Recommendations for businesses}

The environment factor plays a significant role in customers' orientation to an e-commerce site. At this point, the concept of positive word of mouth marketing stands out. When the customer, whose problem has been solved and his/her loss is compensated, if any, shares it with those around him/her, the company will be preferred more. Since customers are more inclined to share their dissatisfaction, businesses need to attach importance to satisfaction to prevent behaviour that could harm potential customers.

When consumers evaluate the effects of e-service quality and after-sales e-service quality dimensions on satisfaction, it has been observed that the privacy dimension is no longer considered as an element of satisfaction by consumers, and the factors that bring satisfaction focus primarily on factors of responsiveness and compensation and then system availability and fulfilment. In the light of the findings of the previous studies, it is recommended that future studies should be carried out to include new consumer expectations. For an e-commerce site, it is thought that the more importance it attaches to responsiveness and compensation factors, two of the dimensions of after-sales service, the higher the customer satisfaction will be. In addition, helplines (live support, call centres) where consumers can get written or verbal support (live support software, call centres) to answer any questions when they want to ask a question is effective in consumer satisfaction. Also, the customer-satisfactory solution suggestions offered by the website will significantly contribute to the consumers' intention to buy again safely and show loyalty.

Stock and warehouse inspections should be monitored and reinforced when there is a decrease. A product that is not in stock or cannot be supplied when ordered should not be offered to consumers.

\section{Peer-review:}

Externally peer-reviewed

\section{Conflict of interests:}

The author(s) has (have) no conflict of interest to declare. 


\section{Grant Support:}

The authors declared that this study has received no financial support.

\section{References}

Ahmed, R. R., Romeika, G., Kauliene, R., Streimikis, J. \& Dapkus, R., (2020). ES-QUAL Model and Customer Satisfaction in Online Banking: Evidence From Multivariate Analysis Techniques. Oeconomia Copernicana, 11(1),59-93.

Akın, M., Toksarı, M. (2017) "The Effect of Quality of E-Service on E-Loyalty", Journal of Business and Economics Studies (JBES), 5(1), 48-59.

Akınc1, S., 2006. Elektronik Hizmet Kalitesi ve Hizmet Telafi Kalitesinin İnternet Bankacılık Hizmetlerine Uyarlanması. Doktora Tezi. Akdeniz Üniversitesi Sosyal Bilimler Enstitüsü, Antalya.

Akınc1, S., Atılgan-İnan, E. and Aksoy, S., (2010), "Re-assessment of E-S-Qual and E-RecS-Qual in a pure service setting", Journal of Business Research, 63(3), pp.232-240.

Akınc1, S., İnan, E. A., Aksoy, Ş., Büyükküpçü, A. (2009). “Milestones of Service Quality Concept in Marketing Literature", Hacettepe University Journal of Economics and Administrative Sciences, 27(2), 61-82.

Alotaibi, R. S. (2021). Understanding Customer Loyalty of M-Commerce Applications in Saudi Arabia. International Transaction Journal of Engineering, Management, \& Applied Sciences \& Technologies, 12(6), 12A6J, 1-12. http:/ /TUENGR.COM/V12/12A6J.pdf DOI: 10.14456/ITJEMAST.2021.115

Altunışık, R., Sütütemiz, N., Çallı, L., (2010), "A Study on The Determination of Performance Criteria on E-Satisfaction (The Case of E-Retailing)", Academic View | International Refereed Journal of Social Sciences, Vol:20.

Arslan, S., Atalık, Ö. (2016), "E-loyalty on Social Media Sites and Research on the Airlines in Turkey", Academic Review of Economics \& Administrative Sciences, 9(2).

Ateş, V. (2017). Online Alışveriş Sitesi Kaynaklı Müşteri Algılarının Müşteri Memnuniyetine Etkilerinin İncelenmesi. Gaziantep Üniversitesi Sosyal Bilimler Dergisi, 16(2), 313-329.

Bakır, M. (2017), An Integrated Approach to The Evaluation of E-Service Quality in Airline Companies, PhD Thesis, Department of Civil Aviation Management Anadolu University, 33-37.

Barenji A.V., Wang, W.M., Li Z., Guerra-Zubiaga D.A. (2019), "Intelligent E-commerce Logistics Platform Using Hybrid Agent-Based Approach", Transportation Research Part E 126, 15-31.

Barnes, S.J., Vidgen, R. (2001), "An evaluation of cyber-bookshops: The WebQual method", International Journal of Electronic Commerce, 6, 11-30.

Barnes, S.J., Vidgen, R.T. (2002), "An Integrative Approach to the Assessment of E-Commerce Quality", Journal of Electronic Commerce Research, 3(3), 114-127.

Bearden, W. O., Teel, J. E. (1983), “Selected Determinants of Consumer Satisfaction and Complaint Report", Journal of Marketing Research Vol: 20, 21-28.

Bilgihan, A., Bujisic, M., (2014), "The Effect of Website Features in Online Relationship Marketing: A Case of Online Hotel Booking", Electronic Commerce Research and Applications, 1-11.

Boshoff, C., (2007), "A Psychometric Assessment of E-S-Qual: A Scale to Measure Electronic Service Quality", Journal of Electronic Commerce Research, 8(1), 101-114.

Bozbay, Z., Yaman, Y., Özkan, E. (2016), “The Role of Service Quality on Customer Satisfaction in Internet Retailing: A Comparative Study of Apparel and Book Industries", Journal of Transportation and Logistics, 1(1), 19-38.

Buckley, J. (2003). E-Service Quality and the Public Sector. Managing Service Quality, 13(6), 453- 462.

Cadotte, E. R., Woodruff, R. B., Jenkins, R. L. (1987), “Expectations and Norms in Models of Consumer Satisfaction", Journal of Marketing Research Vol:24, 305-14.

Churchill, G. A., Surprenant, C., (1982), "An Investigation into the Determinants of Customer Satisfaction", Journal of Marketing Research, 491-504. 
Collier, J., E., Bienstock, C., C. (2006), “Measuring Service Quality in e-Retailing", Journal of Service Research, 8(3), 260-275.

Connolly, R., Banister, F., and Kearney, A. (2010), “Government Website Service Quality: A Study of The Irish Revenue Online Service", European Journal of Information Systems, 19, 649667.

Çelik, H. (2009), "How Far Could We Ignore Online Shopping Anxiety When Explaining The Customer Intentions To Utilize Virtual Retail Storefronts?", Uludag Journal of Economy and Society, 28(2), 93118.

Çelik, H., Başaran, B. (2008), "Perceived Electronic Service Quality by Individual Customers", Anadolu University Journal of Social Sciences, 8(2), 129-152.

Çelik, K., Özköse, H., Güleryüz, S., (2018), “Structural Equation Modeling With R”, Eurasian Journal of Social and Economic Research (EJSER), 5(10), 38-48.

Çelik, K., Sökmen, A., (2018a), “The Effect of Perceived Performance on the E-Learning Users' Satisfaction", Turkish Studies Information Technologies \& Applied Sciences. 13(21), 73-92.

Çelik, K., Sökmen, A., (2018b), “Understanding Distance Education Continuance Intention: Extended Technology Acceptance Model", Journal of Management, Economic and Marketing Research, 2(3), $1-23$.

Dabholkar, P. A. (1996), “Consumer Evaluations of New Technology-Based Self-Service Options: An Investigation of Alternative Models of Service Quality", International Journal of Research in Marketing, 13(1), 29-51.

Ding, D. X., Hu, P. J. H., Sheng, O. R. L. (2011), “e-SELFQUAL: A Scale for Measuring Online Self-Service Quality", Journal of Business Research, 64(5), 508-515.

Doğan, H., Burucuoğlu, M. (2018), “Consumers' Perceived Service Quality of and Intention to Re-Use Mobile Banking: An Empirical Study", Journal of Management Economics and Business, 14(4), 11831198.

Durmuş, B., Erdem, Y. C., Özçam, D. S., Akgün, S. (2015), “A New E-Trade Model in Turkish Clothing Sector: Elektronic Retailing Offer", Journal of Marmara University, 11(44), 17-32.

Durukal, E., Okursoy, A., Armağan, E. (2019), “An Analysis of The Effect of Electronic Customer Management Applied in Airline Company on e-Loyalty by Structural Equation Modeling", Journal of Current Researches on Business and Economics, 9 (1), 61-84.

Düger, Y. S. ve Kahraman, H. (2017). Online Alışverişte Hizmet Kalitesinin Ve Algılanan Değerin Müşteri Memnuniyeti İle Tekrar Satın Alma Niyeti Üzerindeki Etkisi. Journal of International Social Research, 10(54), 819-826.

Erçetin, C., Arıkan, E. (2020), “E-Service Quality, E-Satisfaction, E-Stickiness and E-Loyalty Behaviors: A Study on E-Retail Shopping Sites", Dokuz Eylul University Faculty of Business Journal, 21 (1), 6793. DOI: 10.24889 /ifede.563879.

Faiz, E. (2018), "The Effect of Service Quality of Online Travel Shopping on the E-Satisfaction and ELoyalty", Electronic Journal of Social Sciences, 17(68).

Fornell, C., Larchker, D. F. (1981), “Evaluating Structural Equation Models with Unobservable Variables and Measurement Error", Journal of Marketing Research, 18(1).

Francis, J. E. (2007), “Internet Retailing Quality: One Size Does Not Fit All”, Managing Service Quality, 17(3),341-355.

Francis, J. E., White, L. (2002), “Exploratory and Confirmatory Factor Analysis of The Perceived Internet Retailing Quality Model", ANZMAC 2002 Conference Proceedings, 1791-1796.

Grönroos, C. (1984), “A Service Quality Model and Its Marketing Implications”, European Journal of Marketing, 18(4), 36-44.

Güllülü, U., Uçan, Ö., F., Karabulut, T. (2016), “The Measurement of The Service Quality of The Web Sites Selling Book, and The Service Quality's Effect on Perceived Value and Loyalty Intention Thereby Using Esqual; A Research on The Academicians of Erzincan University", Journal of Economics and Administrative Sciences, 30(1), 121-141.

Hair, J. F., Black, W. C., Babin, B. J., Anderson, R. E. (2010). Multivariate Data Analysis(7ed.). Upper Saddle River, NJ: Pearson Education. 
Hou, Y., (2005), Service Quality of Online Apparel Retailers and Its Impact on Customer Satisfaction, Customer Trust and Customer Loyalty, (PhD Thesis), The University of North Carolina.

https://www.eticaret.gov.tr, (Accessed: 15.10.2020)

https://www.hepsiburada.com, (Accessed, 21.10.2020)

Iacobucci, D., Duhachek, A. (2003), “Advancing Alpha: Measuring Reliability with Confidence”, Journal of Consumer Psychology, 13(4), 478-487.

İlter, B. (2009). “E-Perakendecilikte E-Hizmet Kalitesi, Müşteri Memnuniyeti ve Müşteri Sadakati İlişkisi: İşletme Fakültesi Öğrencileri Üzerine Bir Çalışma", Dokuz Eylül Üniversitesi İşletme Fakültesi Dergisi, 10 (1), 97-117.

Jaiswal, A., K., Niraj, R., Venugopal, P., (2010), “Context-General and Context-Specific Determinants of Online Satisfaction and Loyalty for Commerce and Content Sites", Journal of Interactive Marketing, 24, 222-238.

Jones, S. M., Wilikens, P. M, Masera, M. (2000), “Trust Requirements in E-Business: A conceptual framework for understanding the needs and concerns of different stakeholders", Communications of the ACM 43(12). 81-87.

Karadeniz, M. ve Çuhadaroğlu, Ö. (2016). "Lojistik Yönetiminde E-Ticaret Mobil Uygulamlarında Sunulan Hizmet Kalitesinin Müşteri Memnuniyetine Etkisi". Atatürk Üniversitesi İktisadi ve İdari Bilimler Dergisi, 30 (1), 155- 173.

Kim, J. H., Kim, C. (2010), “E-Service Quality Perceptions: A Cross-Cultural Comparison of American and Korean Consumers", Journal of Research in Interactive Marketing, 4(3), 257-275.

Kim, M., Kim, J., Lennon, S.J., (2006), “Online Service Attributes Available on Apparel Retail Web Sites: An E-S-QUAL Approach”, Managing Service Quality: An International Journal, 16(1), pp.51-77.

Kotler, P., Keller, K. L. (2006). Marketing Management. New Delhi: Prentice-Hall of India.

Labarbera, P. A., Mazursky, D. (1983), “A Longitudinal Assessment of Consumer Satisfaction/Dissatisfaction: The Dynamic Aspect of the Cognitive Process", Journal of Marketing Research, 393-404.

Latifah S. (2018). "E-Procurement Service Quality in Malaysia”. ASEAN Marketing Journal, 85-95.

LaTour, S. A., Peat, N. C., (1979), “Conceptual and Methodological Issues In Consumer Satisfaction Research", Advances in Consumer Research, 431-7.

Lee, G. G., Lin, H. F. (2005), "Customer Perceptions of E-Service Quality in Online Shopping", International Journal of Retail \& Distribution Management.

Lee, Y. J., Yang, S., and Johnson, Z. (2017), "Need for Touch and Two-Way Communication in Ecommerce", Journal of Research in Interactive Marketing, 11(4), 341-360.

Leonnard (2019) 'Exploring the Relationship Among E-service Quality, E-trust, E-satisfaction and Loyalty at Higher Education Institutions', Journal on Efficiency and Responsibility in Education and Science, 12(4). 103-110. http://dx.doi.org/10.7160/eriesj.2019.120401.

Li, H., Suomi, R. (2009), "A Proposed Scale for Measuring E-Service Quality", International Journal of U-And E-Service, Science and Technology, 2(1), 1-10.

Loiacono, E. T., Watson, R. T., \& Goodhue, D. L. (2007), “WebQual: An Instrument for Consumer Evaluation of Web Sites", International Journal of Electronic Commerce, 11(3), 51-87.

Loiacono, E.T., Watson, R.T., Goodhue, D.L., (2002), "Webqual: A Measure of Website Quality", American Marketing Association, (Winter 2002), 432- 438.

Madu, C. N., Madu, A. A. (2002), "Dimensions of E-Quality", International Journal of Quality \& Reliability Management, 19(3), 246-258.

Menon, B. (2018), “The Influence of E-Relationship Quality and E-Service Quality on Customer Loyalty in The Context of Flipkart Online Retailer Services", Journal of Customer Behaviour, 17(1-2), 121137.

Niranjanamurthy, M., Kavyashree, N., Jagannath, S., Chahar, D. (2013), “Analysis of E-Commerce and M-Commerce: Advantages, Limitations and Security Issues", International Journal of Advanced Research in Computer and Communication Engineering, 2(6), 2360-2370. 
Novak, T. P., Hoffman, D. L., Yung, Y. (2000), “Measuring The Customer Experience in Online Environments: A Structural Modeling Approach", Marketing Science, 19(1), 22-42.

Nunallly, J. C. (1978). Psychometric theory (2 b.). New York: McGraw Hill.

Oliver, R. L. (1997). Satisfaction a Behavioral Perspective on the Consumer. McGraw-Hill.

Oliver, R. L., (1980), "A Cognitive Model of the Antecedents and Consequences of Satisfaction Decisions", Journal of Marketing Research 17, 460-9.

Ozment, J., Morash, E.A. (1994), “The Augment Service Offering for Perceived and Actual Service Quality", Journal of Academy of Marketing Science, 4(22), 352-363.

Özgüven, N. (2008), "Customer Satisfaction in The Marketing of Services and Its Application Ege Academic Review", Ege University Faculty of Economics and Administrative Sciences, 8(2), 652-682.

Pandya, A., Dholakia, N. (2005), "Conceptualizing B2C Business as a New Category of Services", Journal of Electronic Commerce in Organizations, 3(1), 1-12.

Parasuraman, A., Zeithaml, V. and Malhotra, A., (2005), "E-S-QUAL: A Multiple-Item Scale for Assessing Electronic Service Quality", Journal of Service Research, 7(3), 213-233.

Parasuraman, A., Zeithaml, V., Berry, L., (1988), “SERVQUAL- A MultipleItem Scale for Measuring Consumer Perceptions of Service Quality", Journal of Retailing, 64, 12-40.

Rafiq, M., Lu, X., Fulford, H. (2012), "Measuring Internet Retail Service Quality Using ESQUAL", Journal of Marketing Management, 28(9-10), 1159-1173.

Rathmell, J. M. (1966), “What is Meant By Services?”, Journal of Marketing, 30(4), 32-36.

Rayport, J. F., Sviokla, J. J. (1995), “Exploiting the Virtual Value Chain”, Harvard Business Review, 73(6), 75-85.

Rayport, J.F., Sviokla, J.J. (1994), “Managing in the Marketspace”, Harvard Business Review, 72(6), 123150.

Ridwandono, D., Suryanto, T. L. M. And Suherlan G. I., (2020), Electronic Service Quality and Perceived Value in Mobile based Services, Proceedings of the International Conference on Culture Heritage, Education, Sustainable Tourism, and Innovation Technologies (CESIT 2020), pages 592-598.

Rita, P., Oliveira, T., Farisa, A. (2019), “The Impact of E-Service Quality and Customer Satisfaction on Customer Behavior in Online Shopping", Heliyon, 5(10), e02690. doi:10.1016/j.heliyon.2019.e02690.

Santos, J. (2003), "E-Service Quality: A Model of Virtual Service Quality Dimensions", Managing Service Quality: An International Journal, 13(3), 233-246.

Saydan, R. (2010), Customer Satisfaction. Varinli, İ., Çatı, K. (Editors). Selections from Current Marketing Approaches. 2. Edition. Ankara: Detay Publishing, 105-125.

Söylemez, C., Karahan, M. O., (2020), E-Hizmet Kalitesi ve Güvenin Mobil Uygulama Kullanma Memnuniyetine Etkisi, Atatürk Üniversitesi İktisadi ve İdari Bilimler Dergisi, 34(2): 555-575, DOI: 10.16951/atauniiibd.669579

Suki N.M., Ramayah T., Suki N.M. (2008), "Internet Shopping Acceptance Examining the Influence of Intrinsic Versus Extrinsic Motivations", Direct Marketing: An International Journal 2(2) 97-110.

Szymanskia, D. M., Hise, R., T., (2000), “E-satisfaction: An Initial Examination”, Journal of Retailing. 76(3). 309-322.

Şenel, B., Şenel, M., Gümüştekin, G. E. (2012), “According to E-Service Quality, Evaluated Virtual Shopping Sites", Dumlupınar University Journal of Social Sciences, (33).

Ulkhaq, M., Rabbani, M., Wibowo, A. T., Rachmania, B. A. (2017), “Assessing Electronic Service Quality Using E-S-QUAL and E-Recs-QUAL Scales". ITMSOC Transactions on Innovation \& Business Engineering, 2017; 2: 20-26.

Wolfinbarger, M., Gilly, M.C., (2003), "eTailQ: Dimensionalizing, Measuring and Predicting Etail Quality". Journal of Retailing, 79(3),183-198.

Wu, K.W., (2006), Service Quality, Customer Satisfaction and Customer Loyalty in Consumer Electronics E-Tailers: A Structural Equation Modeling Approach, (PhD Thesis), Lynn University. 
Yang, Z., Jun, M., Peterson, R. T. (2004) “Measuring Customer Perceived Online Service Quality: Scale Development and Managerial Implications", International Journal of Operations \& Production Management, 24(11), 1149-1174.

Yaşin, B., Özkan, E., Baloğlu, S. (2017), “The Role of Consumers' Satisfaction, Trust and Perceived Quality on Loyalty to Online Retail Sites", İstanbul Management Journal, 28(83), 24-47.

Yellaturu, S., Gagggutara, R., (2021), "Mediating Role of Perceived Value Between Service Quality and Consumer Satisfaction: Evidence From Indian Online Stores", International Journal in Management and Social Science, 9(5), 17-33.

Ylldız, B. (2020), "The Effect of E-Commerce Logistics Service Quality on Trust, Satisfaction and Loyalty", Giresun University Journal of Economic and Administrative Sciences, 6(1), 38-61.

Yi, Y., (1989), "A Critical Review of Consumer Satisfaction, Working Paper 604", University of Michigan School of Business Administration.

Yoo, B., Donthu, N., (2001), “Developing and Validating A Multidimensional Consumer-Based Brand Equity Scale", Journal of Business Research, 52(1), 1-14.

Zeithaml, V. A., Parasuraman, A., Malhotra, A. (2000), “E-Service Quality: Definition, Dimensions and Conceptual Model. Marketing Science Institute", Cambridge, MA, Working Paper.

Zeithaml, V. A., Parasuraman, A., Malhotra, A., (2002), "Service Quality Delivery through Web Sites: A Critical Review of Extant Knowledge", Journal of the Academy of Marketing Science, 30(4), 362-375. 